\title{
Proposal of a Pilot Plant (2T/day) for Solid Fuel Conversion of Cambodian Mango Waste Using Hybrid Hydrothermal Carbonization Technology
}

\author{
Jong-il Han ${ }^{\dagger}$, Kangsoo Lee, Inkook Kang \\ Kinava Co. Ltd, \#701-704 7 Heolleung-ro, Seocho-Gu, Seoul, Korea
하이브리드 수열탄화기술을 이용한 캄보디아 망고 폐기물 고형연료화 실증플랜트 $(2 \mathrm{~T} / \mathrm{day})$ 제안 \\ 한종일†, 이강수, 강인국 \\ (주)키나바, 서울특별시 서초구 헌릉로 7, 701-704호
}

\begin{abstract}
하이브리드수열탄화 (Hybrid HTC) 기술은 2가지 이상의 유기성폐기물을 혼합한 특허 받은 열역학 공정으로 공정온도 $180 \sim 250^{\circ} \mathrm{C}$, 압력 20 40 bar에서 반응시간이 2시간 이내이며 에너지 소비가 적고, 폐기물의 부피감소 및 악취 저감효 과가 크다. 폐기물 중 대부분의 탄소가 최종 생성물에 축적되므로 유기성 폐기물 고형연료화에 가장 적합한 기술로 평 가받고 있다. 본 연구에서는 하이브리드 수열탄화기술을 활용하여 캄보디아 망고 폐기물을 대상으로 온도 및 반응시 간의 변화에 따라 발열량 및 수율 등에 미치는 영향에 대하여 평가하였다. 본 연구를 통해 공정변수를 최적화하고, 전 공정플랜트의 에너지 효율성을 향상시킬 수 있으며, 수연탄화기술에서 분해되어 가스가 생성되는데 이때 수소 $\left(\mathrm{H}_{2}\right)$ 및 메탄 $\left(\mathrm{CH}_{4}\right)$ 등 제조 및 생산기술개발을 할 수 있다. 본 연구 결과를 토대로 망고폐기물(2t/day)실증 물질수지 및 에너지 수지 도출과 함께 경제성도 평가하였다.
\end{abstract}

\begin{abstract}
Hybrid hydrothermal carbonization (Hybrid HTC) technology is a proprietary thermochemical process for two or more organic wastes.The reaction time is less than two hours with temperature range $180 \sim 250^{\circ} \mathrm{C}$ and pressure range $20 \sim 40 \mathrm{bar}$. Thanks to accumulation of the carbon of the waste during Hybrid HTC process, the energy value of the solid fuel increases significantly with comparatively low energy consumption. It has also a great volume reduction with odor removal effect so that it is evaluated as the best solid fuel conversion technology for various organic wastes. In this study of the hybrid hydrothermal carbonization, the effect on the calorific value and yield of Cambodian mango waste were evaluated according to changes in temperature and reaction time. Through the study, parameter optimization has been sought with improving energy efficiency of the whole plant. It is decomposed in the Hydro-Carbonation Technology to Generate Gas. At this time, it is possible to develop manufacturing and production technologies such as hydrogen $\left(\mathrm{H}_{2}\right)$ and methane $\left(\mathrm{CH}_{4}\right)$. Based on the results of the study, a pilot plant (2t/day) has been proposed for future commercialization purpose along cost analysis, mass balance and energy balance calculations.
\end{abstract}

KEYWORDS: Hybrid Hydrothermal Carbonization, Cambodia Mango Waste, Pilot Plant, Bio-SRF, Energy Saving, Reduction

\footnotetext{
${ }^{\dagger}$ To whom correspondence should be addressed.

E-mail: maxim14@naver.com

Received: 5 January 2021, Revised : 3 June 2021,

Accepted: 3 June 2021
} 


\section{서론}

화석연료 사용으로 인한 지구 온난화 문제 등의 심각성 을 인지하고 이를 개선하기 위한 국제적 협력이 필요한 실 정이다. 6 대 온실가스 $(\mathrm{GHG})$ 중에 $\mathrm{CO}_{2}$ 가 $80 \%$ 이상이고 이 산화탄소 배출이 증가함에 따라 지구 온도가 상승하고 있 다. 올해 50 주년을 맞이하는 다보스 포럼은 '결속력 있고 지 속 가능한 세계를 위한 이해관계자들' 이라는 주제로 진행 되었으며, 7대 주제 중 지구 살리기 분야를 살펴보면, 환경 문제와 기후 변화에 대해 경각심을 갖고 화석연료에 대한 의존도를 줄이면서 친환경연료와 자연환경 회복에 대한 투
자 확대 촉구를 제시하였다(Hyundai Research Institute, 2020).

글로벌 친환경 트렌트로 순환경제(Figure 1)가 부각되고 있다. 순환경제개념은 제품을 재활용하고 자원 소비와 환경 오염을 최소화하는 경제구조이며, 제 11차 5자원을 채취하 고 대량생산 이후 폐기되는 선형 경제는 한계를 들어냈으 며, 재활용, 제품 수리 및 업그레이드 등을 통해 자원 사용 을 줄인 순환 경제가 주목받고 있다. 유럽연합(EU)집행위 원회는 순환경제 실천 및 이행 순환경제패키지를 발표하였 으며, 2030년까지 도시 쓰레기 $70 \%$, 포장재 폐기물 $80 \%$ 재 활용을 권고하였다(EucoLight, 2017).

국내에서는 폐기물을 에너지화 하는 정책으로 진행되고
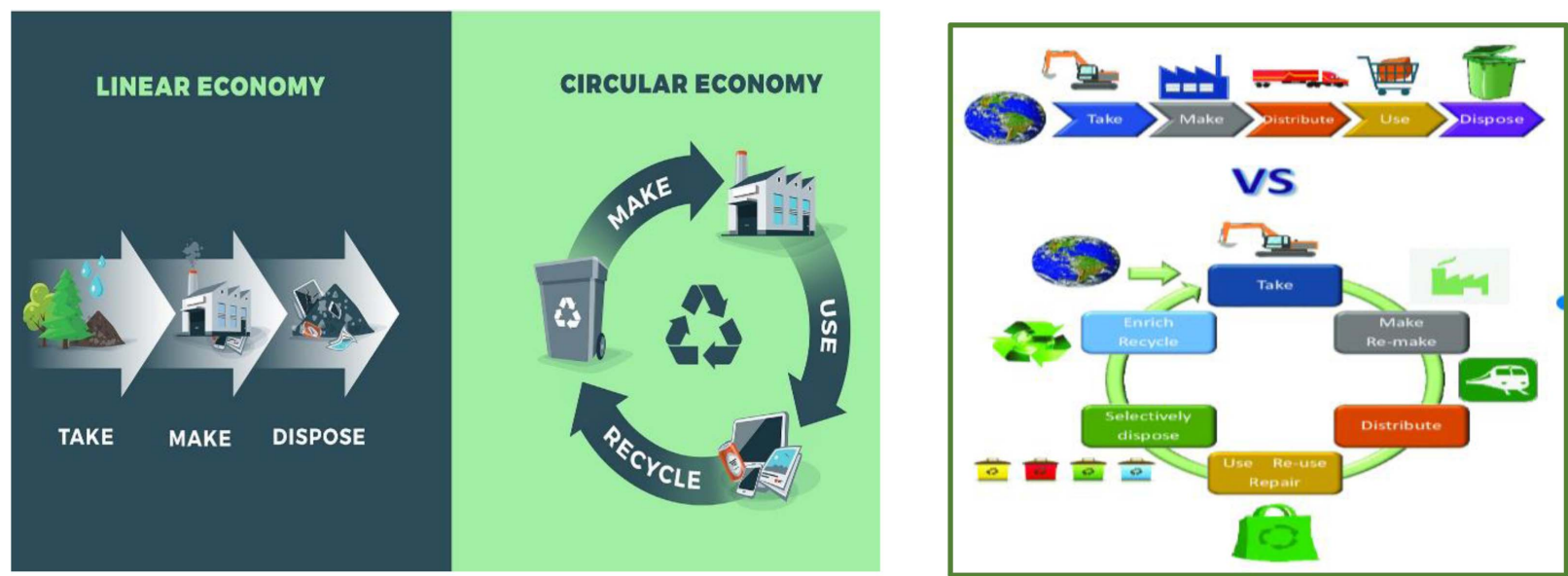

Figure 1. Linear Economy and Circular Economy (https://www.instarmac.co.uk; https://www.researchgate.net/figure)

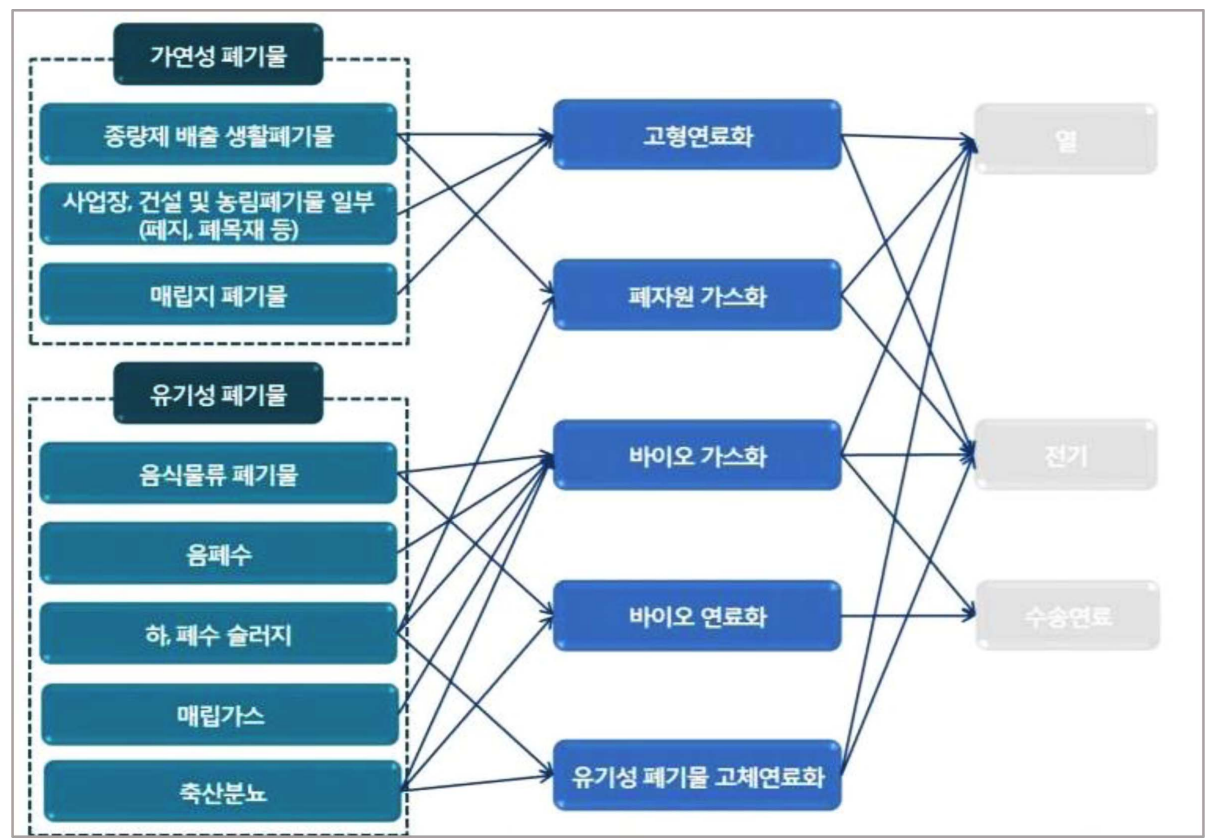

Figure 2. Process of Waste to Energy in Korea (MSS, 2019) 

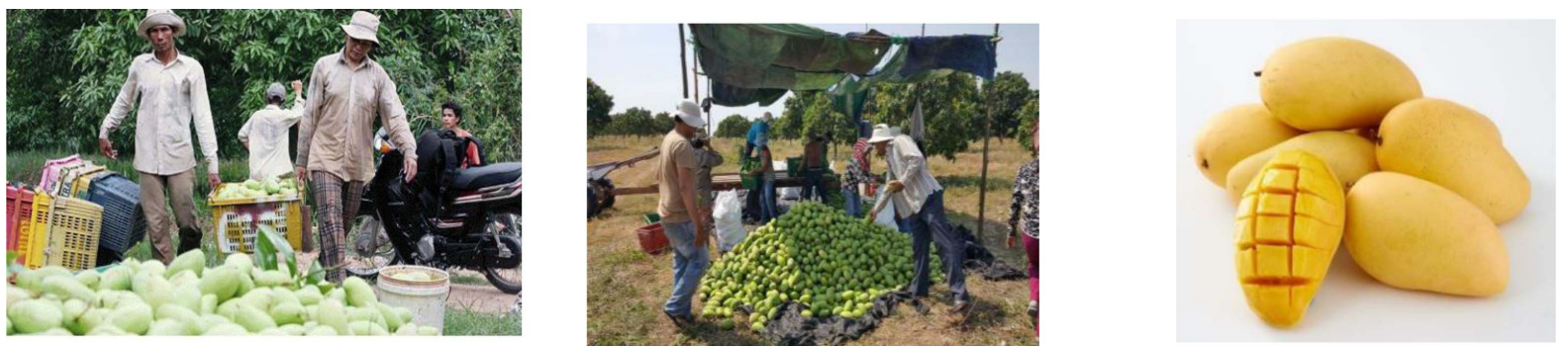

Figure 3. Agricultural Status of Cambodia Mango (https://www.phnompenhpost.com/business/mangoes-bound-european-market)

있으며, 페 기물 에너지는 자원의 절약과 재활용촉진에 관 한 법률 제 1조에 따른다(MSS, 2017). 폐기물에너지 자원 으로는 고체연료, 액체연료, 기체 연료, 소각 열 등이 있으 며, 고체연료의 경우 Figure 2와 같이 고형연료화와 유기 성폐기물 고체 연료화 기술은 폐기물에너지화의 핵심 기 술이다(MSS, 2019).

본 연구에서는 폐기물에너지화의 핵심기술인 고형 연료 화 또는 고체 연료화 기술 중 하나인 수열탄화 기술을 건 조 기술과 비교하고, 수열탄화 기술로 캄보디아 망고를 고 형 연료화 했을 때 물질 수지와 에너지수지를 제시하여 경 제성 분석을 하였다.

\section{캄보디아 농업과 망고 시장 규모}

캄보디아는 국토의 전체면적 중 농업 용지는 $32.1 \%$ 로 매 우 높은 비중을 차지하고 있으며, 2004년부터 2012까지 농 업의 연평균 성장률이 $7 \%$ 로 세계에서 가장 높은 증가율을 보이고 있다(Ministry of Agriculture, Food and Rural Affairs Cambodia, 2017). 또한 농산업으로 $\mathrm{GDP}$ 의 $26 \%$ 를 얻는 국 가이며, 전체 인구의 약 $70 \%$ 가 농산업에 종사하는 만큼 농 업의 비중이 매우 높다.

캄보디아 과일시장 규모는 약 100 억 원 이상으로 추정하 고 있으며, 생산량은 연간 약 약, 260만 톤 규모이며, 이
중 망고가 가장 높다(Weeklytrade, 2016). 그러나 연간 망고 생산량 중 약 13 만 톤(약 $5 \%$ )은 상품가치가 없어서 폐기하 고 있는 실정이며, 폐기되는 망고를 자원화 하는 기술이 필 요한 실정이다.

\section{ㅁ 캄보디아 망고 투자동향}

- 몽르티 그룹은 싱가포르 회사인 King Fruit와 200만 달 러를 공동 투자해 ' 14 년 하반기 캄보디아 의 시하누크 빌 꺼뿌어 지역 $12 \mathrm{ha}$ 면적 부지에 공장 건설 예정이다.

\section{ㅁ 캄보디아 망고 시장}

- 기존 캄보디아 산 망고는 비공식적으로 베트남과 태국 에 수출된 후 가공, 대부분 중국 에 수출되고 있다. 기 존 망고 수입국가는 태국, 필리핀, 대만이며 $99 \%$ 점유, 호주 미국 파키스탄 등 국가에서 총 양의 $1 \%$ 수입하고 있다.

\section{수열탄화(Hydrothermal Carbonization) 기술 및 공정}

\section{- 수열탄화(HTC: Hydrothermal Carbonization)}

수열탄화 과정은 분자구조내의 탄화수소를 탄화물로 바 꾸어 주는 과정으로 고온과 고압의 아임계수(Subcritical

Table 1. Export of mango to neighboring countries in Cambodia

\begin{tabular}{|c|c|c|c|c|c|c|c|c|}
\hline \multirow{2}{*}{ 국명 } & \multicolumn{3}{|c|}{ 망고 금액 } & \multicolumn{5}{|c|}{ 뭍량 } \\
\hline & 금액 & 증감률 & 중량 & 점유율 & 금액 & 증감률 & 중량 & 점유율 \\
\hline 태국 & 6,489 & 56.2 & 1319 & 51.2 & 11,736 & 80.9 & 2447 & 48.5 \\
\hline 필리핀 & 3,378 & 92 & 1085 & 26.6 & 7,992 & 136.6 & 2954 & 33.0 \\
\hline 대만 & 2,661 & -13.6 & 406 & 21.0 & 4,297 & 61.5 & 723 & 17.8 \\
\hline 기타 & 153 & - & 29 & 1.2 & 175 & - & 30 & 0.7 \\
\hline 합계 & 12,681 & 39.7 & 2839 & 100 & 24,200 & 90.8 & 6154 & 100 \\
\hline
\end{tabular}




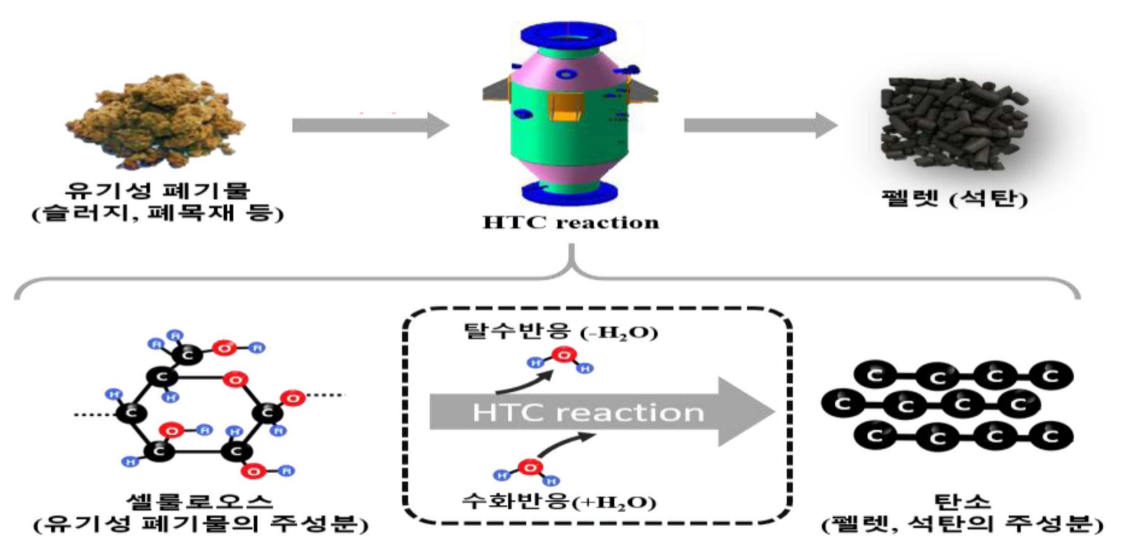

Figure 4. HTC: Hydrothermal Carbonization

water) 조건을 이용하여 유기성 가수분해, 응축반응, 탈-카 르복실화 반응, 탈수반응을 거쳐서 바이오 석탄으로 변환시 켜준다(Figure 4). 좀 더 구체적으로 설명하면, 수열탄화 반 응 $(\mathrm{HTC})$ 이라 함은 물의 초임계 조건 $\left(374^{\circ} \mathrm{C}, 221.1 \mathrm{bar}\right)$ 이하 의 압력과 온도에서 증기(고온 중압) 혹은 물(중온 고압)의 형태일 때 이온성이 최대가 되고 유전율이 감소하는 성질 을 이용하여 무산소 과정에서 공급된 유기물에 열수를 가 하여 유기물에 가수분해, 응축, 탈카르복실화, 그리고 탈수 반응을 일으킴으로써 수소와 산소의 양을 줄여준다. 이 과 정을 통해 휘발성 물질의 양은 감소하고 탄소의 양은 늘려 줘서 최종적으로 생성되는 연료의 열량이 높아지게 된다. 이 반응을 위한 중요 조건들은 온도, 압력, 반응시간 그리고 수 율등이 있다. 수열탄화과정은 건조가 필요 없는 습식과정으 로 가수분해를 이용해 공급 원료의 분자구조 내에 있는 탄 화수소를 탄화물로 바꾸어주는 과정이다(Robert Bunsen 1893년). 이 반응은 발열반응으로서 바이오매스/초본계 바 이오매스(톱밥, 목재부산물, 야자나무 부산물, 커피찌꺼기, 사탕수수) 뿐만 아니라 유기성폐기물(음식폐기물, 슬러지, 커피찌꺼기, 술 찌꺼기, 비지 등 식품가공 부산물, 짚이나 버
섯 배지, 채소 과일 등 농업 부산물, 가축분뇨, 동물 사체 등 축산 부산물, 어류 등 수산폐기물) 그리고 이탄 같은 저 등 급 고형연료(고급석탄급)까지도 원료로 사용할 수 있다.

하이브리드 수열탄화(Hybrid Hydrothermal Carbonization) 하이브리드 수열탄화 공정은 두 가지 이상의 바이오매스 및 유기성폐기물을 혼합하고 적정 촉매를 적용하여 HTC 공 정을 수행하는 기술로서 발열량을 최대 $40 \%$ 까지 높여주며 원하지 않는 유해 물질을 줄여서 환경 친화적인 연료를 만 들어 주는 기술이다. 촉매를 적용한 Hybrid HTC 기술은 반 응 중에 적정한 촉매를 사용하여 발열반응인 탈-복실화과 정을 약화시켜 급격히 온도와 압력이 상승하는 것을 막아 주고, 수열탄화반응 중 발생되는 이산화탄소를 감소시켜 고 분자 성상을 유지하게 하여 별도의 접합제 없이 성형이 가 능하고 동시에 수율도 높여 줄 수 있는 공정이다. 촉매를 사 용한 Hybrid HTC 반응과 무 촉매 수열탄화(HTC) 반응의 조 건은 Table 2 와 같다. 촉매를 사용함으로써 동일한 에너지 밀도를 가정할 때 온도는 $10 \sim 30^{\circ} \mathrm{C}$ 가 감소하고 공정압력은 $0.8 \sim 2.8 \mathrm{MPa}$ 내려가며 반응시간은 최대 3 시간 정도 단축된

Table 2. HTC vs Hybrid HTC

\begin{tabular}{|c|c|c|}
\hline 조건 & 수열탄화 $(\mathrm{HTC})$ & 촉매 Hybrid 수열탄화 (Hybrid HTC) \\
\hline 생산물 & Hydro char material & Branched polymer oxygenated hydrocarbon fuel \\
\hline 반응온도 & $250^{\circ} \mathrm{C}$ & $220 \sim 240^{\circ} \mathrm{C}^{* *}$ \\
\hline 반응압력 & $4.1 \mathrm{MPa}$ & $2.3 \sim 3.3 \mathrm{MPa}$ \\
\hline 반응시간 & 4 hours & 1 hour \\
\hline 자체 접착력 & Poor & $6,450 \sim 6,690 \mathrm{kcal} / \mathrm{kg}$ \\
\hline 에너지밀도 & $5,730 \sim 6,690 \mathrm{kcal} / \mathrm{kg}$ & $\sim 60 \%$ \\
\hline 수율 & $\sim 40 \%$ & \\
\hline
\end{tabular}


다. 또한, 무 촉매 수열 반응(HTC)으로 생성된 차르와 달리 Hybrid HTC 촉매 반응은 리그닌의 고분자특성을 그대로 유 지하여 반응 후 접착력을 유지하고 있으며 수율도 최대 $20 \%$ 더 높게 얻을 수 있다.

이외에도 하이브리드 수열탄화 공정은 다양한 혼합하여 물리화학적으로 단일 연료화 하는 친환경 연료화 기술로서 연료의 경제성, 친환경, 연소효율 등의 목표를 필요에 따라 유연하게 만족시켜줄 수 있는 기술이다. 수열탄화 과정 이 후에는 분자 구조 내에 있는 수소와 산소의 비를 줄어들고 탄소의 비율이 늘어나게 되면서 탄화물로 바꾸어 주게 되 는데 이러한 원리로 인해 발열량을 높여주면서 비교적 저 온에서 반응이 일어나게 된다.

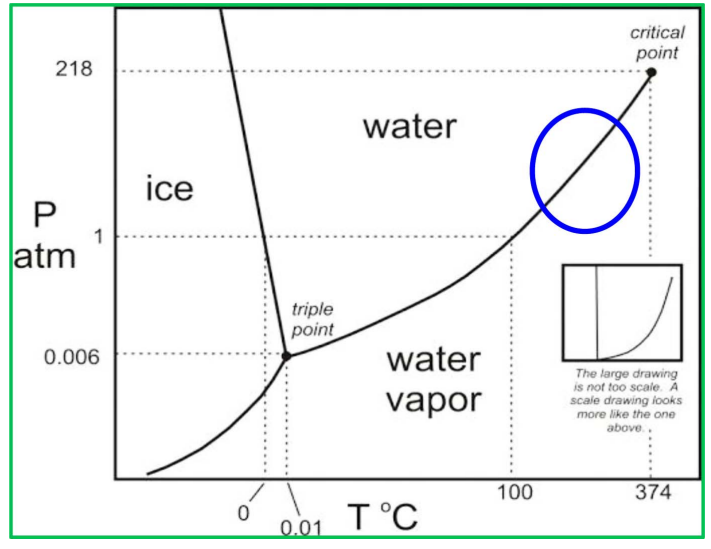

Figure 5. Water phase equilibrium curve

열역학 상평형 $\Rightarrow$ 반응 조건은 Figure 5 를 살펴보면 초 임 계 조건 $\left(374^{\circ} \mathrm{C}, 222.1 \mathrm{bar}\right)$ 이하의 압력과 온도이며, 증기 혹 은 물의 형태일 때 이온 성이 최대가 되면서 유전율이 감 소하는 성질을 이용한다. 이 조건은 건조 열분해 과정(500 $800^{\circ} \mathrm{C}$ 에 비해 비교적 저온 $\left(350^{\circ} \mathrm{C}\right)$ 에서 일어난다.

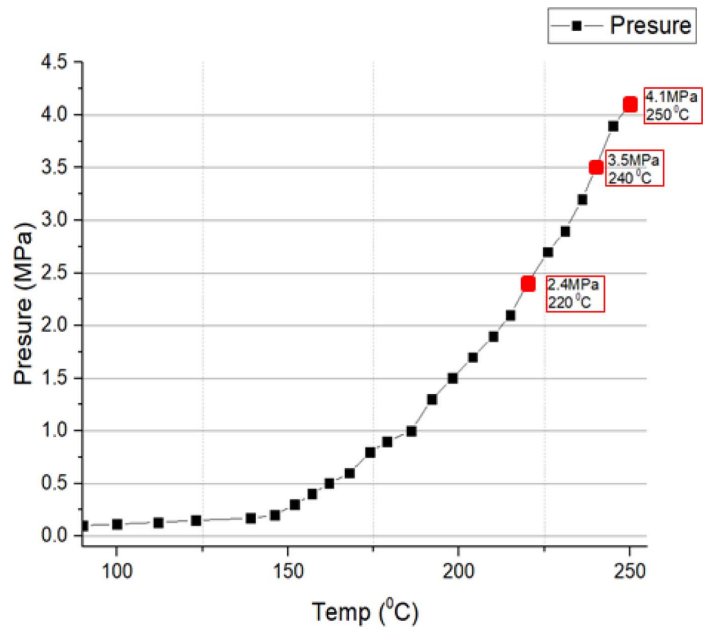

Figure 6. Reaction pressure graph according to HTC reaction temperature

수열탄화 반응이 활발한 온도 분포는 $220 ~ 260^{\circ} \mathrm{C}$ 에서 탄 화과정이 잘 이루어지며, 온도에 따른 반응 압력은 Figure 6 과 같다. $200^{\circ} \mathrm{C}$ 이상부터는 반응압력 변화가 크기 때문에 반응물질에 따른 적절한 반응 온도와 압력 범위를 찾는 것 이 중요하다.

Table 3 과 같이 수열탄화기술은 기존에 많이 사용되는 건 조(dry)기술과 비교하면 경계(아임계)적인 기술이다. 수열탄 화공정기술 무엇보다도 반응물 건조가 필요 없는 습식탄화 기술로써 수분이 많은 유기성 폐기물일수록 에너지 효율이 높아진다.

저위 발열량의 경우 건조 기술의 경우 약 2,000 3,500 $\mathrm{kcal} / \mathrm{kg}$ 에 비해 수열탄화기술의 경우 약 4,000 7000 kcal $/ \mathrm{kg}$ 으로 월등하게 높아진다.

한국-캐나다 에너지 국제공동연구 프로젝트 결과를 살펴 보면, 이미 다양한 유기성 폐기물을 수열탄화기술한 결과로 파일럿 플랜트 설계 및 탄화물(Fig. 7), 유기성 폐기물의 탄

Table 3. Comparison of drying process and HTC process

\begin{tabular}{|c|c|c|}
\hline 구분 & 건조 공정 & HTC 공정 \\
\hline 연구기관 & 일반적인 공정 & (주)키나바 \\
\hline 주요 원료 & \multicolumn{2}{|c|}{ 음식물류 폐기물, 각종 슬러지, 축산분뇨 등의 유기성 폐기물 } \\
\hline 주요 반응 & $100^{\circ} \mathrm{C}$ 이상, 상압에서 수분함량 최소화 & $200^{\circ} \mathrm{C}$ 이상, 고압(약 30bar)에서 고형연료 생산 \\
\hline 발열량 & $\begin{array}{c}\text { 저위 발열량 } \\
\text { 약 } 2,000 \sim 3,500 \mathrm{kcal} / \mathrm{kg}\end{array}$ & $\begin{array}{c}\text { 저위 발열량 } \\
\text { 약 } 4,000 \sim 7,000 \mathrm{kcal} / \mathrm{kg}\end{array}$ \\
\hline 유해물질 & $\begin{array}{c}\text { 폐기물 종류에 따라 유해물질 발생량이 상이하며, } \\
\text { 추가적인 환경 저감 설비 필요 }\end{array}$ & $\begin{array}{c}\text { 다양한 유기성 폐기물을 혼합하거나 촉매기술을 사용하여 } \\
\text { 유해물질 발생 최소화 }\end{array}$ \\
\hline 주요기능 & $\begin{array}{l}\text { - 건조 후 고형 연료로 사용 } \\
\text { - 중량 및 부피 감소시켜 매립 }\end{array}$ & $\begin{array}{l}\text { - 폐기물을 제한없이 혼합 가능 } \\
\text { - 수분 상관없이 원물 그대로 사용 }\end{array}$ \\
\hline
\end{tabular}



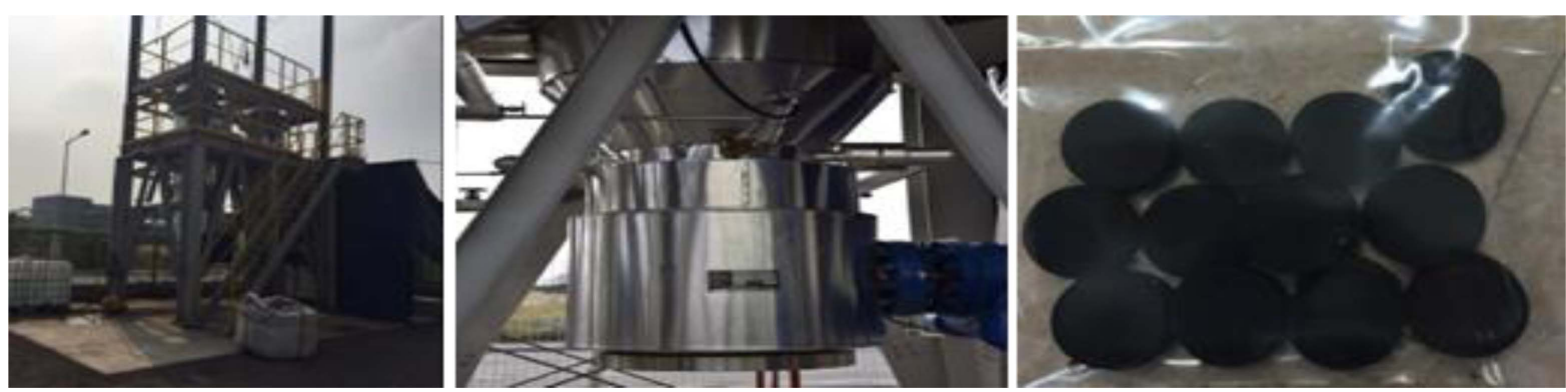

Figure 7. Pilot plant \& Bio coal

소(c)함유량 변화(Table 4)를 통해 바이오매스 연료화 신뢰 성이 검증되었다.

\section{하이브리드 HTC공정용 첨가제(촉매제)연구}

수열탄화(HTC) 공정에 촉매를 첨가하면, 반응 운전조건 (압력, 온도, 반응시간)을 다소 개선기키는 효과가 있다. 혼 합 목질계 및 Biomass용 첨가제 개발 $\left(\mathrm{Cl}\right.$ 계 금속염 $+\mathrm{NO}_{3}$ 화 합물) $\mathrm{LiCl}$ 과 acetic acid의 혼합촉매를 사용함으로써 동일 조건에서 발생하는 자생압력을 낮추어서 운전조건을 개선 하였다.수열탄화(HTC)공정에서 산(Acid)을 추가하여 낮은 $\mathrm{pH}$ 의 조건이 형성되면 $\mathrm{CO}_{2}$ 의 발생량이 줄어들 수 있음을 확인하였다. 황산 $\left(\mathrm{H}_{2} \mathrm{SO}_{4}\right)$ 을 탈수촉매제 역할을 위해 활용하 였다. 수열탄화(HTC), 수열고분자화(HTP)를 수행하여 고열 량의 고형연료 제조방법 제시 및 연료로서의 가치를 평가 및 조사하였다(Table 4).

Table 4. Analysis of organic waste elements after hydrothermal carbonation

\begin{tabular}{|c|c|c|c|c|c|}
\hline 시ㄱㅛㅛ명항목 & $\mathrm{C}$ & $\mathrm{H}$ & $\mathrm{N}$ & $\mathrm{S}$ & $\mathrm{O}$ \\
\hline 우드칩(RAW) & 46.30 & 5.79 & 0.11 & 0.13 & 43.92 \\
\hline palm(RAW) & 51.07 & 5.82 & 0.07 & 0.03 & 42.51 \\
\hline 닭똥(RAW) & 25.57 & 3.75 & 3.60 & 1.29 & 33.54 \\
\hline Saw dust(RAW) & 46.83 & 6.12 & 0.03 & 0.09 & 45.31 \\
\hline 우드칩 & 68.93 & 5.32 & 0.23 & 0.06 & 24.60 \\
\hline palm & 66.94 & 4.92 & 0.14 & 0.04 & 25.13 \\
\hline 닭똥 & 52.80 & 4.87 & 2.57 & 1.01 & 24.18 \\
\hline Saw dust & 66.00 & 4.81 & 0.10 & 0.04 & 25.97 \\
\hline 음식물쓰레기 & 55.71 & 5.73 & 2.27 & 0.56 & 27.24 \\
\hline
\end{tabular}

반응 결과는 아래 Figure 8과 같이 HTC 공정 이후에는 발
열량이 $15 \sim 25 \%$ 향상됨을 확인하였으며, 각각의 Bio coal의 경우도 고순도 가수 분리를 통하여 발열량이 증가함을 알 수 있었다.

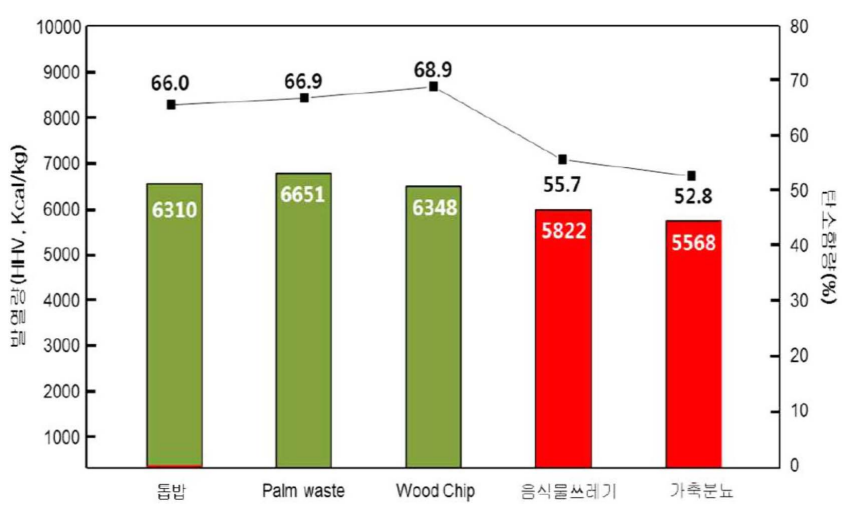

Figure 8. Pilot plant \& Bio coal

\section{망고를 이용한 수열탄화(Hydrothermal Carbonization) 기술 적용 결과}

망고의 함수율은 약 $80 \%$ 로, 수열탄화 반응 조건 중 함수 율 조건에서 최적에 해당한다. 건조 공정 시에는 $80^{\circ} \mathrm{C}$ 조건 으로 유지하면 48시간이 소요될 만큼 함수율이 높은 유기 성폐기물은 건조 공정을 통한 연료화는 경제성이 떨어진다.

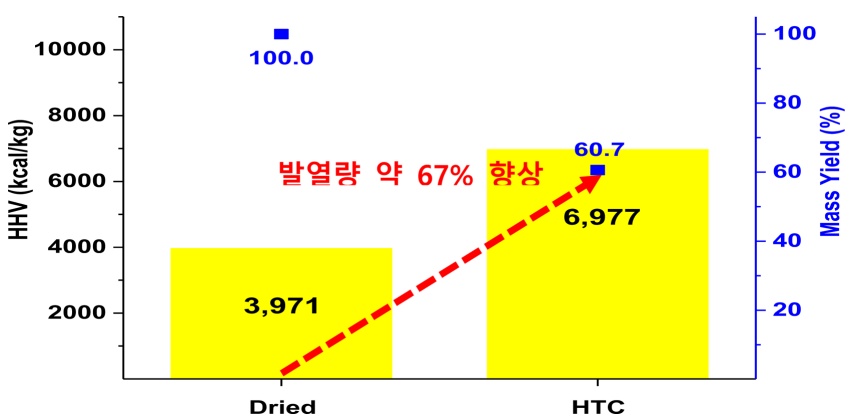

Figure 9. Comparison of reaction results (Dried vs HTC) 
Table 5. Hybrid HTC Results

\begin{tabular}{|c|c|c|c|c|c|c|}
\hline $\begin{array}{c}\text { Mark } \\
\text { (Basis) }\end{array}$ & Reactant & Moisture (\%) & Conditions & $\begin{array}{c}\text { HHV } \\
(\mathrm{kcal} / \mathrm{kg})\end{array}$ & $\begin{array}{c}\text { Mass } \\
\text { Vield (\%) }\end{array}$ & Efficiency $(\eta)$ \\
\hline Dried & Wasted & 80 & Dried at $80^{\circ} \mathrm{C} / 48 \mathrm{hr}$ & 3,971 & 100.0 & 0.8 \\
\hline & Mango & & Reacted at $250^{\circ} \mathrm{C} / 4 \mathrm{hr}$ & 6,977 & 60.6 & 1.8 \\
\hline
\end{tabular}

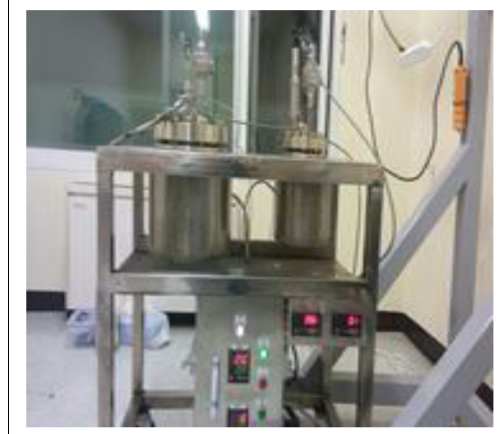

수열탄화 반응기

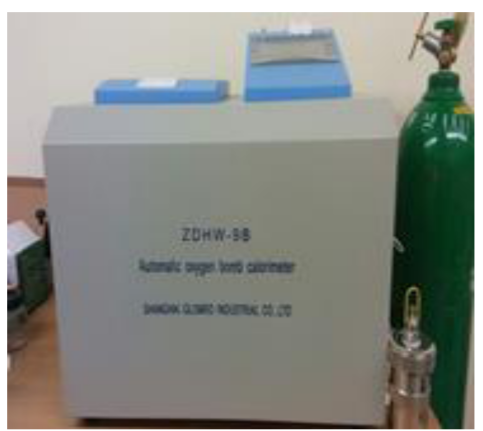

탄화물 열량분석기

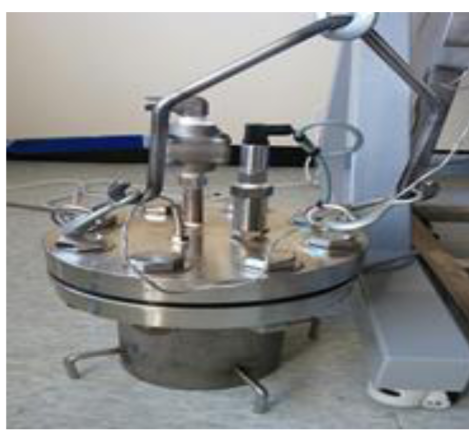

수열탄화반응조

Figure 10. Lab device for Hydrothermal Carbonization

수열탄화 기술을 적용할 경우 $250^{\circ} \mathrm{C}$ 4시간 조건으로도 약 $7,000 \mathrm{kcal} / \mathrm{kg}$ 에 근접한 고위발열량을 나타내었으며, 약 $67 \%$ 증가하였다(Figure 9).

수율은 건조 보다 낮은 $60.6 \%$ 를 나타내었지만, 전체적인 공정 요소(공정 온도, 시간, 발열량, 수율)를 고려하면 수열 탄화 기술은 건조 공정 대비 약 2 배 이상의 효율을 가지는 것으로 계산된다(Table 5). 이 과정에서 사용되는 반응기와 분석기는 다음과 같다(Figure 10).

\section{수열탄화 과정의 촉매반응 메커니즘 규명}

촉매에 의한 수열탄화 과정에 대한 기본 이해를 근간으 로 비전이 균질 촉매에 대한 수열탄화 과정에서의 반응 메 커니즘을 규명하였다.(단, Humins나 Humeric 산의 구조가 아직 분명히 밝혀지지 않은 상태이므로 이러한 범위 내에 서 최대한 반응 원리를 확인) 촉매는 산성이 용해되는 비전 이 균질 촉매 시스템으로 촉매제의 기능은 수성 환경에서 셀룰로오스 안에서 탈수 $\&$ 수화 작용을 활성화 시키는 역할 을 하며 이는 래리우스 방적식으로 화학반응 공정의 속도 를 빠르게 함을 확인할 수 있다.

$$
\mathrm{k}=\mathrm{Ae}^{-\mathrm{Ea} / \mathrm{RT}}
$$

이 식에서 $\mathrm{k}$ 는 반응률, $\mathrm{A}$ 는 반응지수( 1), $\mathrm{Ea}$ 는 활성에너 지, $\mathrm{R}$ 은 기체상수, $\mathrm{T}$ 는 온도이며 촉매제는 활성화 에너지 $\mathrm{Ea}$ 를 감소시키며 이는 특정 온도에서의 단위 시간당 생성되 는 반응물의 양을 증가시켰다. 균일 촉매에 의한 수열공정 은 단순히 탄화에 의한 Char만을 생성시켜주는 것이 아니 고 feedstock이 가지고 있는 자체 고체 고분자를 유지시켜 서 높은 에너지 밀도를 갖는 단단한 형태의 고형연료-펠릿 으로 변환시키는 것이 특징이며 아래와 같은 복잡한 화학 과정을 거친다.

\section{a. step 1. Hydration of the $\beta 1 \rightarrow$ 4bond in cellulose}

촉매에 의한 수열반응의 시작은 촉매에 의해 물 분자가 $\beta 1$ 을 4중결합 셀룰로오스 분자로 전이하는 과정에 유입되 는 수화반응이다.

$\left(\mathrm{C}_{6} \mathrm{H}_{10} \mathrm{O}_{5}\right)_{\mathrm{n}}+\mathrm{H}_{2} \mathrm{O}+\Delta \mathrm{H} \rightarrow\left(\mathrm{C}_{6} \mathrm{H}_{10} \mathrm{O}_{5}\right)_{\mathrm{n}-1}+\mathrm{C}_{6} \mathrm{H}_{12} \mathrm{O}_{6}$ (glucose) $\mathrm{k}=148 \mathrm{kcal} / \mathrm{mole}$ 
반응은 셀룰로오스 분자에 따라 어디서나 일어날 수 있 지만 결합체인의 끝부분에서 일어날 확률이 높고, 셀룰로오 스 분자 다발의 바깥쪽에서 일어날 확률이 높다. 셀룰로오 스 가닥이 수소와 가깝게 결합되면 될수록 반응은 잘 일어 나지 않으며, 셀룰로오스의 결합이 클수록 수화반응은 느리 게 일어난다.

b. step 2. Dehydration of glucose to form 2,5-hydroxylmethyl furfuraldehyde

수화반응에 의해 셀룰로오스에서 떨어져나간 글루코스 분자가 용해물질로 들어가 일으키는 반응 중 가장 중요한 것은 탈수과정에 의한 $2,5 \mathrm{HMF}$ 의 생성으로 글루코스에서 $\mathrm{HMF}$ 으로의 변환은 1,2-Endio을 통해 진행하는 것으로 진행 되며 1,2-Endiol은 Keto-Enol tautomerism을 통해 형성된다.

$$
\mathrm{C}_{6} \mathrm{H}_{12} \mathrm{O}_{6} \rightarrow \mathrm{C}_{6} \mathrm{H}_{6} \mathrm{O}_{3}+3 \mathrm{H}_{2} \mathrm{O} \mathrm{k}=152 \mathrm{kcal} / \mathrm{mole}
$$

c. step 3. Hydration of 2,5 HMF to levulinic acid an formic acid.

$\mathrm{HMF}$ 는 불안정하고 레불린산, 포름산을 형성하도록 반응 하며, 또한 고체 고분자를 형성하기 위해 용액의 다른 성분 과 중합되는 수화반응을 일으킨다.

$$
\mathrm{C}_{6} \mathrm{H}_{6} \mathrm{O}_{3}+2 \mathrm{H}_{2} \mathrm{O}+\Delta \mathrm{H} \rightarrow \mathrm{C}_{5} \mathrm{H}_{8} \mathrm{O}_{3}+\mathrm{CH}_{2} \mathrm{O}_{2} \mathrm{k}=110 \mathrm{kcal} / \mathrm{mole}
$$

\section{d. step 4. Polymerization of HMF and levulinic acid}

셀룰로오스가 글루코스로 그리고 $2,5 \mathrm{HMF}$ 로 그리고 최 종적으로 레블린산/포름산으로 변환하는 과정은 수화와 탈 수가 반복적으로 일어나는 고분자화 과정으로 이 과정에서 촉매는 반응조건을 온화하게 해주는(반응온도, 압력, 반응 시간을 낮춰줌) 역할을 한다(Figure 11).

\section{$\mathrm{HTC}$ 반응조건에 따른 발열량과 질량회수율 변화}

HTC 반응물의 발열량은 Table 6과 같이 반응온도가 증가 함에 따라 함께 증가 하였으나 질량회수율은 감소하였다. 반

Table 6. HTC Heat dissipation change according to heat dissipation

\begin{tabular}{|c|c|c|}
\hline HTC & Calory $(\mathrm{kcal} / \mathrm{kg})$ & Mass yield $(\%)$ \\
\hline sawdust & 4,323 & - \\
\hline $200^{\circ} \mathrm{C}-60 \mathrm{~min}$ & 5,161 & 67.8 \\
\hline $210^{\circ} \mathrm{C}-60 \mathrm{~min}$ & 5,182 & 67.8 \\
\hline $220^{\circ} \mathrm{C}-60 \mathrm{~min}$ & 5,453 & 58.7 \\
\hline $230^{\circ} \mathrm{C}-60 \mathrm{~min}$ & 5,965 & 45.2 \\
\hline $240^{\circ} \mathrm{C}-60 \mathrm{~min}$ & 6,420 & 43.4 \\
\hline $250^{\circ} \mathrm{C}-60 \mathrm{~min}$ & 6,578 & 41.8 \\
\hline $260^{\circ} \mathrm{C}-60 \mathrm{~min}$ & 6,781 & 40.9 \\
\hline $270^{\circ} \mathrm{C}-60 \mathrm{~min}$ & 6,834 & 41.6 \\
\hline
\end{tabular}

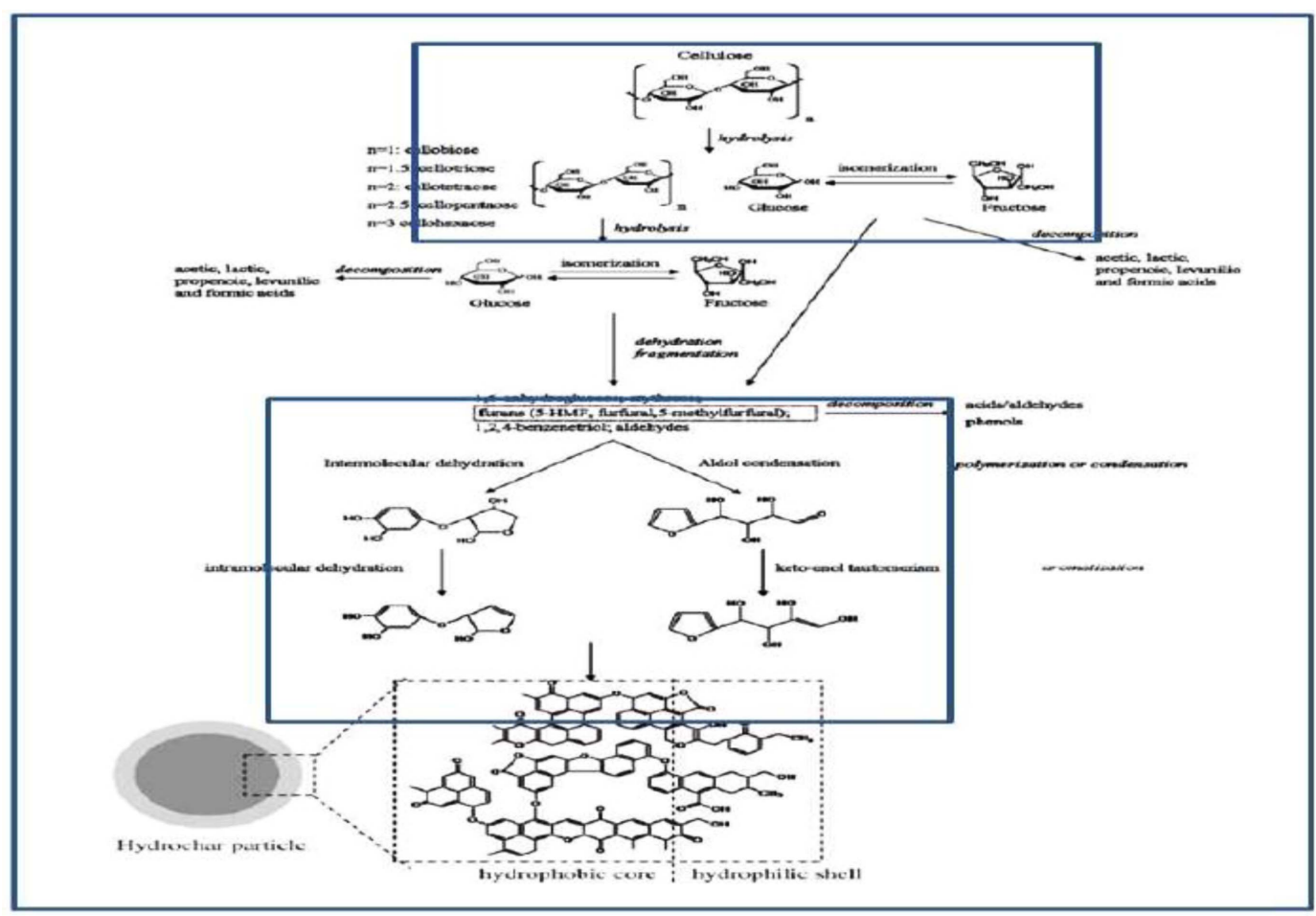

Figure 11. The schematic diagram of the hydrothermal carbonization for glucose 
응온도 $200 \sim 240^{\circ} \mathrm{C}$ 에서 탄화물의 발열량은 급격히 증가하였 으나, $240^{\circ} \mathrm{C}$ 이후에는 발열량 증가에 대한 현저한 차이가 없었으며, 질량 회수율 또한 급격히 감소하지 않았다. 다 음 결과에서 반응 적정온도를 $240^{\circ} \mathrm{C}$ 로 고정하여 반응시간 에 따른 발열량의 변화를 관찰하였으며, Figure 12 와 같이 반응시간 증가에 따라 발열량 또한 증가하는 것을 알 수 있 었다. 반응온도, 시간에 따른 발열량과 질량회수율의 결과 를 도식화 하여 나타냈었다.

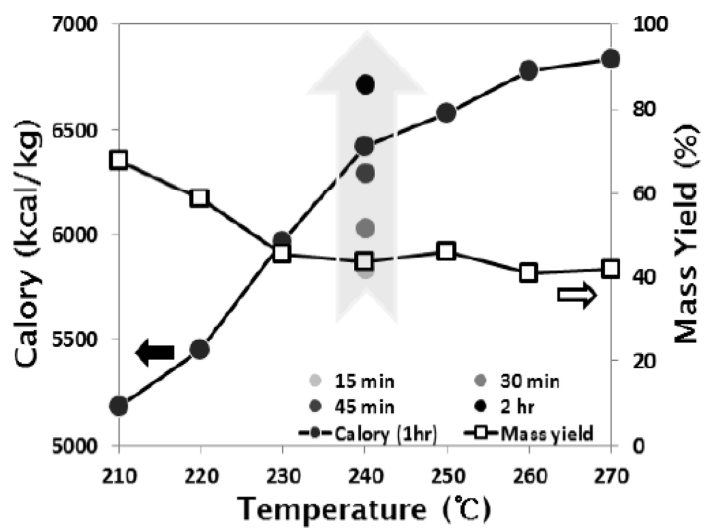

Figure 12. Catalyst Application Heat dissipation change according to heat dissipation

촉매를 첨가하여 온도분포도에 따른 수율을 확인할 수 있 었으며, 각 촉매 별 효과의 수열탄화반응 중 수열탄화가수 분해 반응을 더욱 촉진시키기 위해 염소계 금속 염과 산 (acid)을 첨가하여 발열량 변화를 살펴보았다. 아래의 시간 과 촉매사용, Non-촉매, 수율을 다양한 조건에서 정리하였 다(Table 7).

사용된 $\mathrm{HTC}$ 촉매 중에서는 $\mathrm{CaCl}_{2}$ 의 발열량 증가 효과가 가장 뛰어났으며, $\mathrm{CaCl}_{2}$ 에 산 촉매 $\left(\mathrm{H}_{3} \mathrm{PO}_{4}\right)$ 를 추가하여 $\mathrm{pH}$

Table 7. Non-Catalyst vs Catalyst change according to heat dissipation

\begin{tabular}{|c|c|c|c|c|}
\hline Catalyst & $\begin{array}{c}\text { Temp } \\
\left({ }^{\circ} \mathrm{C}\right)\end{array}$ & $\begin{array}{c}\text { Time } \\
(\mathrm{hr})\end{array}$ & $\begin{array}{c}\text { Calory } \\
(\mathrm{kcal} / \mathrm{kg})\end{array}$ & $\begin{array}{c}\text { Mass yield } \\
(\%)\end{array}$ \\
\hline sawdust & - & - & 4,323 & - \\
\hline non-catalyst & 240 & 1 & 6,420 & 43.4 \\
\hline non-catalyst & 220 & 1 & 5,453 & 58.7 \\
\hline $\mathrm{FeCl}_{3}$ & 220 & 1 & 5,339 & 65.2 \\
\hline $\mathrm{CaCl}_{2}$ & 220 & 1 & 6,056 & 50.1 \\
\hline $\mathrm{LiCl}$ & 220 & 1 & 4,694 & 71.3 \\
\hline $\mathrm{AlCl}_{3}$ & 220 & 1 & 4,406 & 80.5 \\
\hline $\mathrm{H}_{3} \mathrm{PO}_{4}$ & 220 & 1 & 5,601 & 54.6 \\
\hline $\mathrm{CaCl}_{2}+\mathrm{H}_{3} \mathrm{PO}_{4}$ & 220 & 1 & 6,384 & 46.0 \\
\hline
\end{tabular}

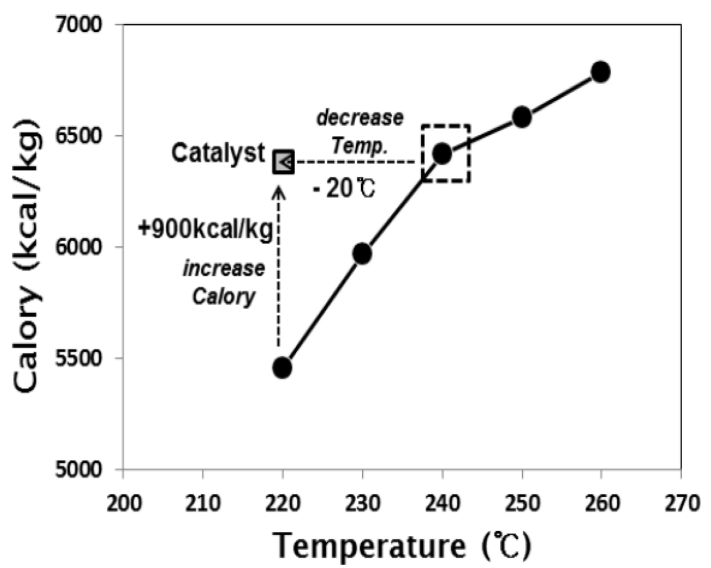

Figure 13. Effect of catalyst application according to the temperature change

를 1.5 2.0로 낮추어 사용한 경우 가장 높은 발열량을 확인 하였다. 반응 후 탄화 여액의 $\mathrm{pH}$ 는 4.5 5.5로 촉매를 이용 하지 않고 증류수만 넣었을 때의 $\mathrm{pH}$ 와 동일한 수준이었으 며, 이는 HTP촉매가 HTP 반응에만 관여 할 뿐 HTP 반응 물의 $\mathrm{pH}$ 에는 무관함을 알 수 있다. 이러한 촉매 첨가 효과 는 낮은 온도에서 고열량의 고형연료를 생산해 낼 수 있으 므로, 열원을 이용한 운전비용 절감의 가능성 보았다(Fig. 13).

\section{$\mathrm{HTC}$ 반응을 위한 촉매 관련 실험 및 촉매 효과 분석 방향}

촉매는 기본적으로 황산계열을 단독으로 사용하는 경우, chloride 계열의 $\mathrm{FeCl}_{3}, \mathrm{CaCl}_{2}, \mathrm{LiCl}, \mathrm{AlCl}$ 금속염과 산 $\left(\mathrm{H}_{3} \mathrm{PO}_{4}\right)$ 을 1 개 또는 그 이상을 혼합하여 사용하는 경우, 고 체계열 촉매를 사용하는 경우로 나누어 증류수에 용해시킨 뒤 $2 \mathrm{~g} / \mathrm{L}$ 농도조건(기준치)의 수용액을 사용하였다. 원료따 른 증류수는 중량비 1:5(함수율 $80 \%$ 이상)가 되도록 섞은 후 촉매용액과 함께 수열탄화 반응기에 투입 후 밀폐하여 실험에 따른 정해진 반응 시간 이후 반출 이후 고형물과 수 용액을 분리 후 수용액은 재사용 하여, 촉매 재사용에 따른 HTP 반응 효과를 확인하였다. 또한, 반응물에 대한 HTC 반 응 효과는 발열량과 수율을 비교하여 판단하며, 촉매 효과 에 따른 비교를 통해 최적의 촉매를 개발하였다.

\section{캄보디아 망고를 이용한 고형연료공정 및 열 및 물질수지(Heat \& Mass balance)}

Figure 14의 공정도를 살펴보면 4톤/hr 처리가 가능한 분 쇄기를 통해 망고 폐기물을 전 처리하며, 다단수열탄화기 2 set로 구성하여 에너지 회수 효율이 증가시킬 수 있다. 탄 화물은 고액분리기와 건조기를 거쳐서 함수율을 $12 \sim 15 \%$ 까 


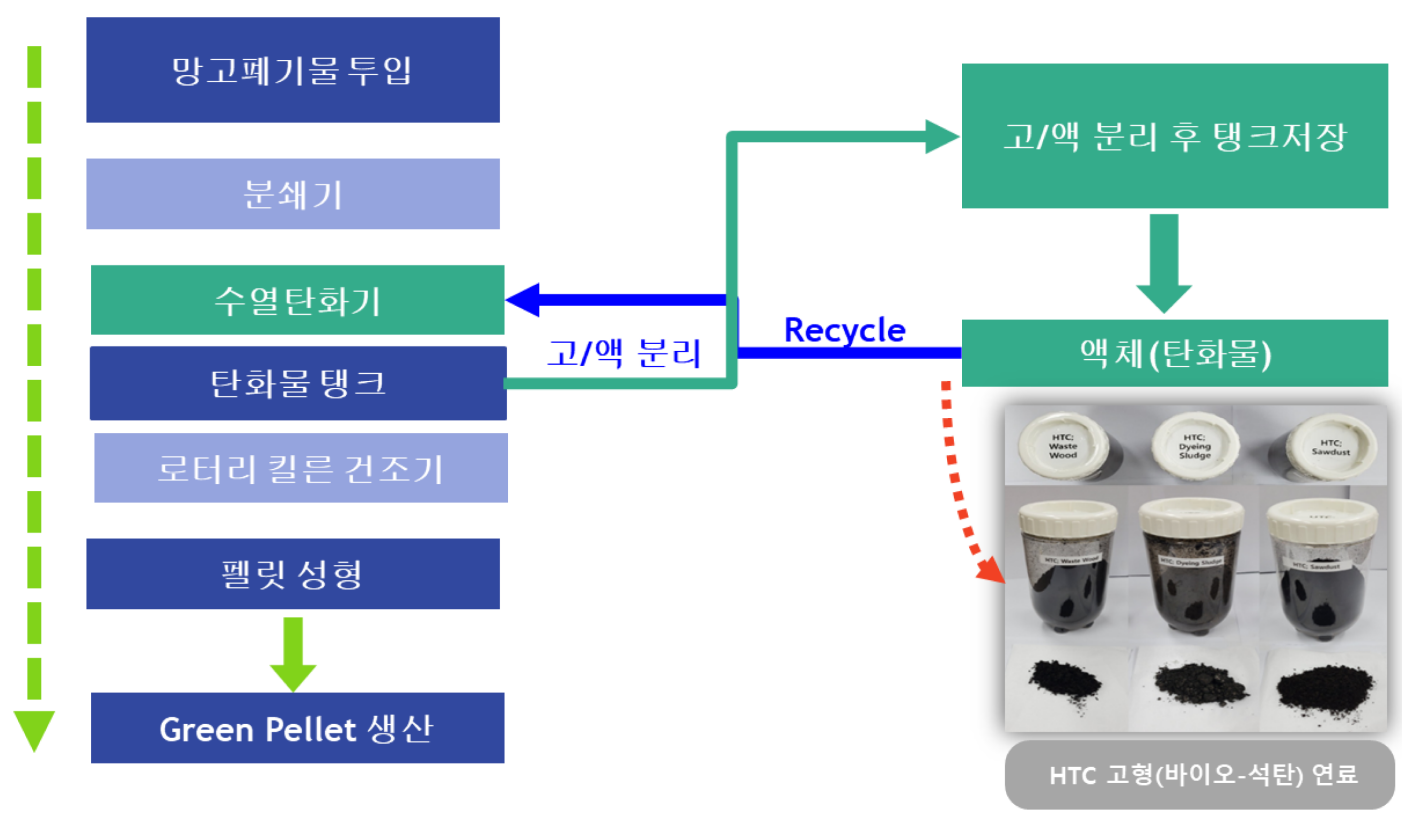

Figure 14. Process diagram of solid fuel production using mango waste

지 감소시켜서 펠릿제조기를 통해 그린 펠릿(고형연료)을 생산하게 된다. 수열탄화 하는데 필요한 증기는 하루에 3.4 톤이 필요하며, 수열탄화 이후에는 오히려 잉여증기가 5.1 톤이 발생하기 때문에 에너지 회수가 중요한 역할을 하며, 잉여증기는 분쇄 저장조와 건조기에 투입되어 에너지 방출 을 최소화하였다.

열 \& 물질수지를 살펴보면 $6 \mathrm{~T} / \mathrm{d}$ 을 생산하는데 필요한 망 고 폐기물은 30 톤 $/ \mathrm{d}$ 필요하다. 필요 열량의 경우 $5,400 \mathrm{Kcal} /$ $\mathrm{d}$ 를 필요하다면 건조 공정의 경우 $5,400 \mathrm{kcal}$ 가 필요하다고 볼 때 $\mathrm{HTC}$ 공정은 $1,890 \mathrm{kcal}$ 가 필요하므로 건조 공정에 비 해서 $35 \%$ 열량만 필요하다. 제시한 공정에서는 초기 외부 스팀 공급 이후 연속 공정이 진행되면, 수열탄화 공정 이후 에 소화조를 거치면서 메탄이 발생하게 된다.

이 메탄을 가스 보일러를 통해 증기를 4.9 톤/d 생산하므 로 실제 공급 증기량은 하루에 0.9 톤이 된다. 따라서 필요 열량에 따른 필요 스팀 9.8 톤/d이며, 이는 건조공정에서 필 요한 스팀이 되며, 수열 탄화의 경우 초기 스팀 제외하고 연 속공정시의 증기(steam)만을 비교하면 에너지 자급률이 $90.8 \%$ 가 되므로 상당히 경제적이다. 특히, 아래공정에서 망 고 폐기물을 이용한 고형연료 제조공정 및 수열탄화물생성 되는 폐수 및 고/액분리생성물 재활용(원가절감)할 수 있다.

\section{1) 상용플랜트 기본(개념) 및 상세설계}

KINAVA 기술 라이선스 확보를 위한 상용화급 (30t/y 생 산기준)상용화급 플랜트 $\mathrm{EPC}$ 설계하고자합니다. 특히, 핵심 원천기술(수열반응기, 공정운전기술) 개발 기반으로 하는
플랜트 엔지니어링 기술 확립 및 정립등 하였습니다.

엔지니어링 기술 사업화를 위한 BEP(Basic Engineering Package) 구축하고자 합니다. 특히 Process Design Package (PDP), HE\&MB, PFD, P\&ID 및 각 분야별(기계, 전기, 계 장, 배관 등) 설계 도출 $\Rightarrow \mathrm{FEED}$ 설계 및 Lay out, data sheet 등 도출하였습니다.

\section{2) 캄보디아외 동남아시아, 유럽, 북미등 사업타당성 조사} (Feasibility Study)

향후에 폐 망고, 바나나, 파인앤플, 커피, 오렌지등 뿐만 아니라, 유기성폐기성(폐목재, 톱밥, 하수, 축분 등) 슬러지 외 활용하여 유럽, 아시아, 아프리카 및 남미의 커피열매 및 찌꺼기(브라질, 볼리비아, 페루 등) 수열탄화 사업화를 위한 기술검증, 시장조사 및 경제성 분석 수행 계획 중이다.

특히, 동아시아 뿐만 아니라, Bioenergy Europe에 따르면 "바이오매스는 EU-28내에서 2017년 최종 에너지 소비의 $10 \%$ 이상을 차지하는 주요 재생에너지원으로써 열, 운송 및 전기와 같은 모든 최종 에너지 사용 형태로 이용되며, 유럽 기후 목표 달성에 기여하는 핵심 요소로 에너지믹스에 상 당한 이점을 제공"한다고 밝혔다.

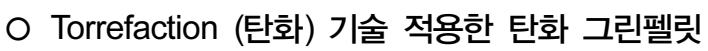

- '90년대부터 저온 열분해 분야에 대한 기초 연구가 유 럽에서 수행되기 시작하였음. 저온 열분해를 응용하여 바이오매스 반 탄화에 대한 연구가 목재류를 대상으로 유럽 및 미국에서 연구가 시작되고 있는 단계이다. 
- 탄화기술개발은 유럽연합과 북미 지역에서 활발히 이 루어졌으며, ECN (Energy Research Center of the Netherlands)에서 기초연구를 바탕으로 파일럿 설비 및 상용화 개발이 활성화 되었고, 유럽연합은 상용화 진입 단계, 북미 지역은 상용화 직전인 것으로 파악되었다.

- '13년 7월 World bank에 이은 유럽투자은행에서는 탄 소배출기술을 수립하면서 대부분의 석탄화력발전소 신 설 및 개조에 대한 지원 중단을 발표했지만, 예외 조항 으로 열병합발전 및 $\mathrm{CCS}$ 활용, 특히 바이오매스 혼소 시 자금지원이 가능한 것으로 발표하여 바이오매스 활 용에 대한 관심이 지속적으로 증가할 것으로 전망된다.

- 유럽연합 9개국 및 21 개 기업이 참여하는 탄화 기술개 발 프로젝트(Production of Solid Sustainable Energy Carriers by Means of Torrefaction, SECTOR)를 '12년부 터 42개월 동안 1,029 만 유로화를 투입하여 연구를 수 행하고 있으며, 로드 맵에 의하면 반탄화 기술 상용화 는 2016년으로 예상하고 있고, 이후 탄화펠릿의 상용 화가 확산될 것으로 전망된다.

- 유럽 및 미국에서는 우드 펠릿 품질 외에 탄화 연료와 같은 열처리된 연료에 대한 품질 기준도 마련(Fuel spec. and Classes; EN ISO 17227-8) 3)되었다.

- 네덜란드의 신·재생에너지 전문 정부 연구기관인 $\mathrm{ECN}$ (Energy Research of the Netherlands)에서는 '03년부터 탄화 기술 연구를 수행하였다. 네덜란드의 Troftech사에 서는 체류시간이 짧고 열전달효율이 우수한 유동층 방
식의 TORBED 탄화 기술을 개발함. 2011년부터 입자 가 작은 하이브리드원료 및 톱밥을 대상으로 60 천톤/y 탄화 제품을 생산하고 있다.

- ANDRITZ 사에서는 $275-285^{\circ} \mathrm{C}$ 의 온도에서 목질계 바 이오매스를 탄화시켜 펠렛으로 제조하는 2 가지 기술을 개발함. 하나는 2011년부터 중소형규모로 50 250천톤 /년 규모의 킬른 형 실증플랜트(ACB Torrefaction process) 를 이용해 다양한 바이오매스를 대상으로 운전하고 있 으며, ' 12 년부터 우드칩을 대상으로 한 700 천톤/년 대 용량 규모의 수직 형 반응기 실증플랜트를 $\mathrm{ECN}$ 함께 공 동 협력하여 개발하였다.

- 이외에도 프랑의 Thermya 사의 Torspyd, 네덜란드 Strampory Green Tech 사의 Oscillating belt dryer, 오스 트리아의 Andrtiz사, 미국의 New Biomass Energy사, 벨 기에의 Renogen사, 스페인의 Idema사 등에서 다양한 반-탄화 기술을 개발하고 있으며, 사업화를 위해 노력 을 하고 있다.

\section{캄보디아 망고를 이용한 추진계획 및 최종목 표 및 수립}

경제성 분석 및 설비 타당성

유기성 폐기물 수열탄화 반응 실험을 위한 환경 설비 구 축하고자 한다 다양한 폐기물과 환경오염 파괴하는 물질을 용광로처럼 수열탄화기술로 하여금 고부가치생산제품으로

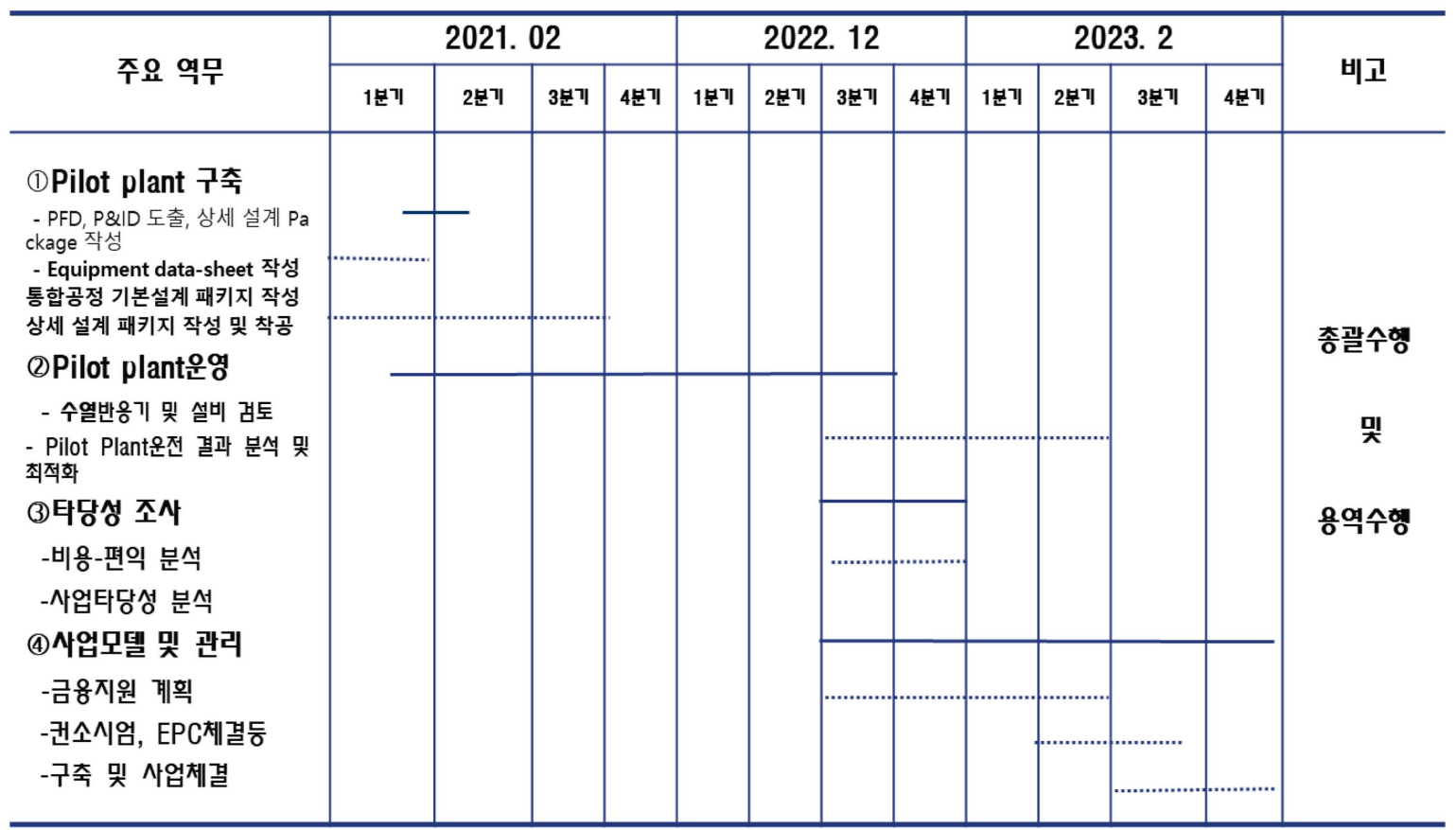


제조 및 생산기술로서 폐기물 리사이클링 및 커피찌꺼기 및 열대과일껍질, 하수 슬러지, 축분순으로 수열탄화 반응 실 험 수행하고자 한다. 또한, 동남아시아 외 아프리카등에서 생성되어 있는 폐 목재와 다른 유기성 폐기물을 혼합하여 수열탄화 반응 수행 후 하이브리드(폐목재+유기성폐기물) 고형펠릿 생산을 위한 적절한 혼합하여 진행 및 추진계획 이다.

수열탄화 반응 전과 후의 반응물에 대한 성분 분석 후 고 형연료 펠릿 적용 가능성 확인과 연구 수행된 고형연료-펠 릿과 비교 하여 수열탄화 반응 조건(압력, 온도, 반응 시간)에 따른 결과 분석하였다. 각각의 유기성 폐기물을 성분과 특 성 파악하고 이를 이용한 고형연료-펠릿 생산을 위한 최적 의 수열탄화 반응 조건 결정하였다.

\section{O 수열고분자화(촉매를 첨가한 수열탄화) 반응 실험}

- 연구개발 된 촉매를 바탕으로 열대과일 및 폐-과일껍 질, 커피찌꺼기 및 하이브리드(폐목재 + 다른 유기성 폐기물) 순으로 촉매를 첨가하여 수열 고분자화 반응 실험 진행 할 계획이다. 성분으로 수열고분자화 반응 물에 대한 성분 분석 후 고형연료-펠릿 적용 가능성 확 인하였으며, 향후에 사업 진행하는데 도움이 될 것으 로 사료된다. 본 연구에서 각각의 수열탄화 반응과 비
교하여 수열고분자화 반응 조건(촉매 성분, 촉매 비율, 압력, 온도, 반응 시간)에 따른 결과 분석하여 $\mathrm{D} / \mathrm{B}$ 화 할 수 있었다.

- 30t/d 고형연료(그린)펠릿 생산 제조 설비를 이용하여 유기성 폐기물을 이용한 그린펠릿 생산 연구 플랜트 설 비를 지속 활용하여 스케일 업(Scale-up) 중요한 $\mathrm{D} / \mathrm{B}$ 로 사용할 수 있을 것이다. 각각의 다른 유기성-폐기물, 하 이브리드에 대하여 순차적으로 적용하여, 고형연료-펠 릿 생산 최적화를 위한 현장 실험 진행과 폐목재 뿐만 아니라 다른 유기성 폐기물, 커피찌꺼기등 하이브리드 를 이용한 고형연료 상용화를 이용한 플랜트 제조 설 비 설계에 활용 계획이다.

\section{캄보디아 망고 열\&물질수지 도출(2t/d)}

\section{결론 및 요약}

캄보디아는 농·식산업으로 전체 GDP의 약 $26 \%$ 를 차지하 고 있으며, 망고는 생산량이 연간 260만톤으로 생산량이 가 장 높은 열대과일이다. 하지만 폐 망고는 연간 13만톤이 발 생하며, 현재 캄보디아에서는 이를 매립하고 있는 실정이 다. 이 때문에 폐기물 에너지화 측면에서 매립하고 있는 폐

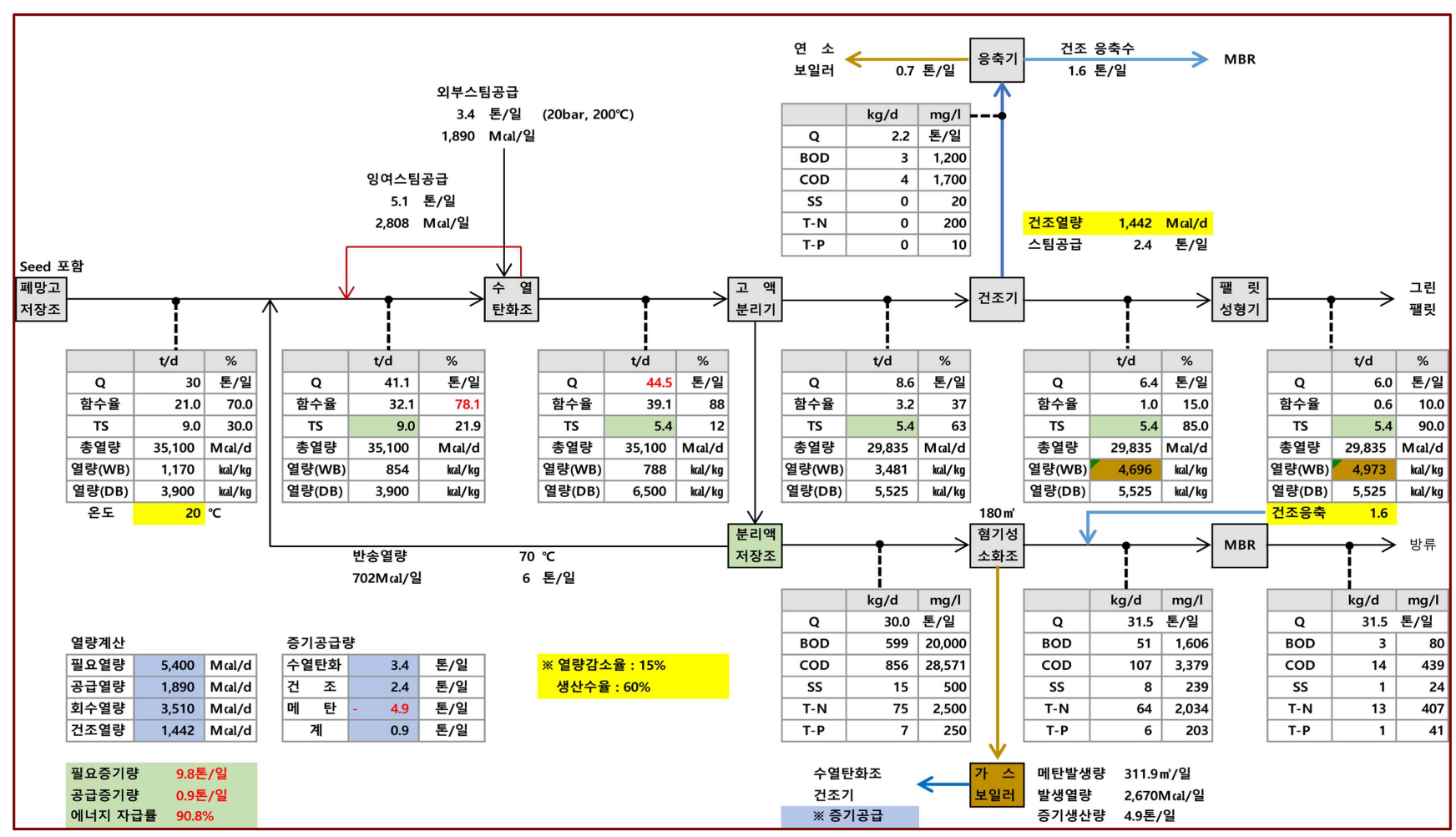

Figure 15. Solid fuel mass balance and energy balance using mango waste 
망고를 연료화 하는 기술이 필요하다. 수열탄화(HTC) 기술 은 수분 함량이 높은 유기성 폐기물(커피찌거기, 음식물, 폐 과일껍질, 폐과일슬러지 등)을 원물 그대로 사용할 수 있는 폐기물 에너지화 기술이며, 이미 다양한 유기성 폐기물을 통 해 연료 화가 가능함을 입증하였으며, 파일럿 설비 실증으 로 상용화가 가능하다.

폐 망고에 HTC 기술을 적용한 결과, 기존 건조된 고형물 보다 고위발열량이 약 $67 \%$ 증가됨을 확인하였으며, 공정효 율은 건조 공정 보다 약 2 배 이상으로 나타났음을 확인하 였다. 본 연구의 결과를 토대로 폐 망고 고형연료 시스템을 상용화 한다면, 캄보디아에서 버려지는 폐 망고를 에너지화 하여 글로벌 친환경트렌드에 맞춰 순환 경제를 이룰 수 있 으며, 경제성 확보를 통한 사업화가 가능하기에 30 톤/일급 폐 망고 고형연료 시스템 공정 설계 안을 제시하였다.

\section{○ 강점·약점}

- 환경 및 미세먼지 배출 등으로 여론이 악화되어 발전 소 폐쇄 조치 혹은 신규 사업 중단 등의 가능성이 있 으나 본 연구로 생산되는 연료는 회분이 더 적고 타르 등이 제거되어 친환경 연료로 사용이 가능하여 정부의 신재생에너지 정책에도 부합될 것으로 기대한다.

\section{O 기회·위협}

- 현재 42개 $\mathrm{OECD}$ 국가들은 석탄연소에 대한 온실가스 $(\mathrm{GHG})$ 감축프로그램 시행으로 탄소 생성 및 오염가스
배출을 규제하고 있는 상황이다. $\mathrm{OECD}$ 회원국은 온실 가스의 주범인 석탄을 2015년까지 $20 \%$ 감축하기로 합 의 하였고 이는 이산화탄소 12.5 억 톤을 발생시키는 석 탄을 매년 500만 톤을 줄이고 있는 추세이므로, 기존 설 비에 적용 가능한 대체 연료 개발이 시급하다. 본 연구 로 생산되는 연료는 기존의 화석연료등을 대체할 친환 경 연료로 사용이 가능할 것으로 기대한다.

\section{References}

EucoLight. (2017). Press release - Circular Economy Package Waste Legislative Proposals

Hyundai Research Institute. (2020). Executive summary, Weekly Economic Review

Ministry of Agriculture, Food and Rural Affairs Cambodia. (2017). Korea Agro-Fisheries \& Food Trade Cooperation Family Site

Ministry of SMEs and Startups (MSS). (2017). Technology roadmap for SME

Ministry of SMEs and Startups (MSS). (2019). Development of organic waste to energy or bio SRF by using the hydrothermal polymerization and combined swirling combustion, 1425136190, KINAVA.

Weeklytrade. (2016). Cambodian Mango could be imported? https://www.weeklytrade.co.kr/news/news_print.html?section $=1 \&$ no $=16237$ (accessed Jun. 2021) 